\title{
PNEUMA EN PASTOR IN DIE PASTORALE BRIEWE
}

DIE plek van die hulpwetenskappe in die amptelike vakke, veral Pastoraal en Kategetiek, het deur die jare baie diskussie en meningsverskil uitgelok.' Inderdaad het die hulpwetenskappe 'n baie belang. rike rol om te vervul in die Pastorale wetenskap, veral in die ontleding van eksistensiële situasies, bv. die sterfbedsituasie ${ }^{2}$ of rousmartsituasie. ${ }^{3}$ Ook die Psigologie van die verskillende leeftydsfases ${ }^{4}$ kan ' $n$ belangrike hulpmiddel wees in die herderlike bediening. Die praktyk van die Pastorale gesprek vereis ook hulp en kennis van die hulpwetenskappe, bv. van Kommunikasiekunde en Psigologie. ${ }^{5}$ Dit moet vir ons vas staan en ons moet dit aanvaar dat die hulpwetenskappe belangrike diens kan en wil bied vir die amptelike vakke.

Die vakwetenskaplike pastorale literatuur van die afgelope tien jaar in S.A. het dan ook tot 'n groot mate gehandel oor die plek van veral die Psigologie ${ }^{6}$ en Antropologie ${ }^{7}$ in die beoefening van die pastoraat. Dit was 'n welkome, nuwe beklemtoning in die Pastorale literatuur. Die onlangs verskene proefskrif van J. J. de Klerk ${ }^{8}$ toon 'n tendens om weer meer die Bybelse gegewens te versamel, te rangskik en te beklemtoon.

Skrywer hiervan is oortuig dat die huidige beklemtoning in die amptelike vakke van gereformeerde kant meer die karakter moet dra van 'n dieper ontginning van die gegewens wat die Skrif self bied. Dink net wat sou 'n eksegeties-homiletiese dieptestudie oor 'n onderwerp soos: „Die begrip verkondiging in die Nuwe Testament", nie vir die Homilitiek kon beteken nie. 'n Dieptestudie oor die begrip „koinonia" in die boek Handelinge kan waardevolle beginsels bied vir die herderlike bediening deur die amp van die gelowige. In dieselfde trant kan ook die vraag gestel word: Moet die Pneumatologie in prediking, pastoraat en kategese nie ook meer beklemtoon word nie? Ons leef immers in die bedeling van die Gees! Die gevaar van verpsigologisering van bv. die pastoraat kan alleen voorkom word as die uitgangspunt in die Pneumatologie geneem word.

In die lig van bg. oortuiging moet hierdie artikel oor Pneuma en Pastor in die Pastorale Briewe gesien word. Dié artikel wil probeer om 'n dieptesnit oor die onderhawige gegewens te bied.

In die Pastorale Briewe, dié sentrale openbaring oor die herderlike bediening, staan die Heilige Gees sentraal in verskillende fundamentele aspekte ten opsigte van die pastor. Hierdie stelling word nou ten opsigte van die volgende sake nader uitgewerk:

1. Amp en charisma in die Pastorale Briewe.

2. Parakleet en paraklese.

3. Sekere vereistes wat in die Pastorale Briewe aan die herder gestel word.

4. Die beeld van die huisgesin in die Pastorale Briewe.

5. Samevatting. 


\section{Amp en charisma in die Pastorale Briewe}

1.1. Die begrip charisma in die N.T.: Charisma kan in die N.T. verskillende betekenisse hê. Die eerste en belangrikste betekenis is sekerlik die volle heilsgawe van God in Christus Jesus en die genadevolheid wat dié heilsgawe vir die gelowige meebring. ${ }^{9}$ Die begrip charisma dui in die N.T. verder ook alle gawes aan wat kan dien tot opbou van die gemeente van Christus. ${ }^{10}$ Hierdie verskeidenheid van genadegawes word deur Paulus saamgevat in Rom. 12 en 1 Kor. 12.

Vir ons docleindes is van belang:

(a) Al hierdie gawes is Geestesgawes (1 Kor. $12: 4,7,8,9,11$ ) gawes deur die Gees gewerk en geskenk om die gemeente op te bou.

(b) Die ampte (episkopoi - 1 Tim. 3:2 en Tit. 1:7), presbuteroi ( 1 Tim. $5: 17$ en 19 , Tit. $1: 5$ ) en diakonoi ( 1 Tim. $3: 8$ en 12) is ook bepaalde Geestesgawes tot opbou van die gemeente (Ef. $4: 11$ en 12).

(c) Die leer (didaskalia), die vermaning (paraklese) en die herders (poimenai) is ook Geestesgawes (Rom. $12: 8$ en Ef. 4:11).

Uit bg. blyk dat die herderlike bediening in die N.T. (paraklese), waar die Woord sentraal staan 'n bepaalde charisma is. Herderlike bediening is Geestesbediening!

In die Pastorale Briewe self kom die begrip charisma net twee keer voor, nl. in $1 \mathrm{Tim} .4: 14$ en $2 \mathrm{Tim}$. 1:6. In een geval roep Paulus Timotheus op om nie sy charisma te verwaarloos nie (me amelei) en in die ander geval om sy charisma aan te wakker (anadzōpurein).

Spesifiek in die Pastorale Briewe het die begrip charisma die betekenis van ampsgawe, met die Heilige Gees wat sentraal staan as Uitdeler. ${ }^{11}$

1.2. Die Heilige Gees en die toebedeling van die charisma aan die pastor: Die Heilige Gees staan nie net sentraal t.o.v. die ampsgawe as sodanig nie. Die Heilige Gees beklee ook die beheersende plek in die aanwysing van die pastor en in die toebedeling van die charisma aan die pastor.

Hoe ontvang die bedienaar die charisma? Vier uitdrukkings in die Pastorale Briewe is vir bogenoemde vraagstelling belangrik. Hierdie vier uitdrukkings staan in verband met die profesie en die handoplegging. Die tekste is 1 Tim. $1: 18 ; 1 \mathrm{Tim} .4: 14$ (wat betrek word beide by profesie en handoplegging) en 2 Tim. $1: 6$.

1.2.1. Die profesie in die Pastorale Briewe: Timotheus word aangewys as ampsdraer „kata tas prophēteias” (1 Tim. 1:18). Hier word „kata" in afwyking van die letterlike betekenis gebruik in die sin van "volgens; in ooreenstemming met; in verhouding tot".12 Timotheus word dus aangewys in die nouste verhouding met die profesie wat aangaande hom uitgespreek is.

In 1 Tim. 4:14 staan weer dat Timotheus "dia prophēteias" 
aangewys word. Hier word „dia” i.p.v. „kata” gebruik. Grammatics is daar twee moontlikhede waarvolgens hierdie uitdrukking verstaan kan word. (a) "dia" met akkusatief mv. sou beteken „op grond van die profesieë", (b) "dia" met die genitief ekv. beteken ,langs die weg van profesie". Aan die tweede moontlikheid moet voorkeur gegee word. Die profesie is nie die grond vir Timotheus se aanwysing nie, maar wel die middel waardeur, of die weg waarlings Timotheus aangewys word.

Profesie word egter ook as 'n Geestesgawe aangedui in Rom. $12: 7$. Daarom kan die volgende afleidings gemaak word:

1. Die Heilige Gees wys die pastor aan.

2. Die Heilige Gees gee aan die gemeente die charisma (in Timotheus se geval profesie) om die bedienaar aan te wys.

3. Die Heilige Gees gee aan die pastor die charisma (1 Tim. 4:14) om deur die gemeente aangewys te word.

1.2.3. Die handoplegging in die Pastorale Briewe: Wat beteken die handoplegging? In 1 Tim. $4: 14$ word die handoplegging aangedui met "meta epitheseỏs". ,Meta" met die genitief druk hier 'n begeleidende aksie uit. ${ }^{13}$ Die Heilige Gees skenk dus aan Timotheus die charisma onder die gepaardgaande, uitwendige aksie van handoplegging. Nie die handoplegging gee die charisma nie, maar wel die Heilige Gees. Die handoplegging is dus 'n simbool van die skenking van die charisma.

En tog is die handoplegging ook meer as net simbool van die charisma deur die Gees. Dit blyk uit 2 Tim. 1:6 waar die uitdrukking "dia tēs epitheseōs" gebruik word. „Dia" met die genitief dui aan dat die Heilige Gees die charisma skenk langs die weg van handoplegging as ,een individualiserende toedeling van de gave van Christus voor een speciale dienst". ${ }^{14}$ In die handoplegging „krijgt deze mededeling van charisma gestalte".15

Die betekenis van die handoplegging in die Pastorale Briewe is dus dat dit enersyds ' $n$ simbool is van die charisma van die Heilige Gees en andersyds ' $n$ gestaltegewing van die mededeling van die ampsgawe deur die Heilige Gees is.

Dit is opvallend dat die handoplegging (1 Tim. 4:14) geskied deur "tou presbuteriou”, d.w.s. deur die ouderlinge van die plaaslike gemeente. Die bevestiging in die amp geskied dus in die gemeente met handoplegging deur die ouderlingekorps van die plaaslike gemeente ( rov $\pi \rho \varepsilon \sigma \beta v \tau \varepsilon \rho \iota 0 v$ ). In die lig hiervan moet die vraag hier gestel word waarom handoplegging by die eerste bevestiging van 'n bedienaar vandag net geskied deur medebedienaars - dikwels besoekers - en nie ook deur die plaaslike ouderlinge nie? Volgens 1 Tim. 4:14 is dit duidelik dat die plaaslike ouderlinge deelneem aan die handoplegging - waarom geld die handoplegging dan nie ook vir elke ouderling by sy eerste bevestiging as ouderling in die plaaslike kerk nie?

1.3. Die verantwoordelikheid van die pastor t.o.v. die charisma (ampsgawe) van die Heilige Gees: Die Gees skenk die ampsgawe. 
Die pastor moet egter iets daarmee doen. Wat die pastor se verantwoordelikheid is, word aangedui in 2 Tim. 1:6. Timotheus moet die genadegawe ,aanwakker" - anadzopurein. Hierdie is 'n hapax legomenon en dit lyk asof die verskillende samestellende dele van die woord nog volle krag het. Ontleed in sy samestellende dele, ana (= weer) $+d z \bar{o} \bar{e}$ (lewe) + pur (vuur) beteken die uitdrukking aanwakker, dus om opnuut en aanhoudend lewe in die vuur te blaas t.o.v. die ampsgawe.

Dat die Heilige Gees hier die beslissende plek beklee, word bevestig deur die spraakgebruik i.v.m. die Heilige Gees in ander gedeeltes in die N.T. Enersyds word die Heilige Gees dikwels in verband gebring met vuur - Matt. 3:11; Hand. 2:3;1 Thess. 5 : 19. Andersyds word die Heilige Gees in die N.T. dikwels in verband gebring met lewe - vgl. Joh. $6: 63$; Rom. $8: 2$ en 6 en Gal. $5: 25$.

Dus, Die Heilige Gees is nie net Skenker van die ampsgawe nie, maar vervul ook die sentrale plek by die aanwakker van die ampsgawe.

Inderdaad kan die aanwakker net geskied as die pastor vervul is met die Heilige Gees.

\section{Parakleet en Paraklese in die Pastorale Briewe}

2.1. Die begrip parakalein: Die begrip parakalein kan beskou word as die sentrale begrip vir die herderlike bediening in die N.T. ${ }^{16}$

In die Nuwe Testament het die begrip parakalein veral vier gebruiksvelde: ${ }^{17}$

a. Om iemand biddend te versoek (Mark. $7: 32$ ).

b. Om iemand vermanend toe te spreek.

c. Om troostende hulp of bystand te bied ( 2 Kor. $7: 6$ ).

d. Vertroosting deur mense en as daad van God.

In die Pastorale Briewe self kom die begrip parakalein nege maal voor as verkondigingsbegrip. Dit is geen wonder dat die sentrale begrip vir die pastorale bediening so dikwels juis in die Pastorale Briewe voorkom nie! En dan in agt uit nege gevalle in die sin van vermanend aanspreek.

2.2. Die Heilige Gees en die paraklese: Die gebruik van die begrip parakalein in die N.T. veronderstel deurgaans twee belangrike sake:

a. Die versoeningswerk van Christus. ${ }^{18}$

b. Die kragvolle werking van die Heilige Gees. ${ }^{19}$ „Bei allen diesen Worten mahnenden Zuspruchs handelt es sich ... um Erweisungen der Kraft des Heiligen Geistes". ${ }^{\text {o }}$

Hoe kan dit immers ook anders - die paraklese word in Rom. $12: 8$ aangedui as 'n charisma van die Gees!

In die N.T. is geen ander begrip wat die H.G. so sentraal stel as die begrip paraklese nie. 
Is dit nie die kern in die herderlike bediening nie?

'n Ouderling of predikant kan die hulpwetenskappe volkome beheers. Hy kan 'n wyse mensekennis hê. Maar as hy vergeet dat pastorale werk Geesteswerk is, is alles verniet!

Parakleet en paraklese is onafskeidelik verbonde!

\section{Die Heilige Gees en sekere vereistes wat die Pastorale Brie- we vir die pastor stel}

3.1. Die vereiste van sōphrōn - sōphronismos - sōphronein: Beide in 1 Tim. $3: 2$ en Tit. $1: 8$ word die vereistes van "sōphrōn" aan die pastor gestel. In Afrikaans word genoemde begrip op beide plekke weergegee met ,ingetoë".

Wat is die plek van die Heilige Gees by die vereistes van ingetoënheid?

In 1 Petr. $4: 7$ word die uitdrukking, ,sōphronēsate... eis proseuchas" gebruik. Ingetoënheid word hier verbind met die gebed. Dit is opmerklik dat die plek van die Heilige Gees in die gebed so sterk beklemtoon word in Rom. $8: 26$.

In 2 Kor. $5: 13$ word sōphronein gebruik in die sin van ,by ons verstand wees". Direk daarna, in vers 14, word die motivering gegee. Ons moet by ons verstand wees ,want die liefde (agapé) van Christus dring ons". Agape word in Gal. 5:22 as eerste vrug van die Heilige Gees genoem.

In 2 Tim. 1:7 word "sōphronismos" as uiterste deug en werking van die Heilige Gees in die gelowige kind van God aangedui: God het ons 'n gees (pneuma!) van krag en liefde en selfbeheersing (sōphronismos) gegee. As klimaks van die werking van die Gees word „sōphronismos" laaste genoem!

3.2. Die vereiste egkratēs - egkrateia - Tit. 1:8: Die nou verband tussen egkrateia en sōphronismos in die N.T. is opvallend. In 2 Tim. 1:7 word sōphronismos genoem as hoogste deug en werking van die Heilige Gees in die gelowige. In Gal. 5:22 word egkrateia genoem as hoogste vrug van die Heilige Gees.

Uit hierdie kort uiteensetting is dit redelik om af te lei dat beide sōphrōn en egkratēs by uitstek dié deugde is van die deur die Heilige Gees beheersde lewe van die pastor.

\section{Die Heilige Gees en die beeld van die huisgesin in die Pastorale Briewe}

Die beeld van die huisgesin word in die Pastorale Briewe ook betrek by die vereistes wat aan die pastor gestel word -1 Tim. $3: 4$ en Tit. 1:6. Die beeld van die huisgesin word deur Paulus self ook betrek op die gemeente van God (1 Tim. 3:5). Die gemeente is „die huis van God" ( 1 Tim. 3:5). Dit is verder opvallend dat die herderlike optrede ook in verband met die verhouding in die gesin (1 Tim. $5: 1$ ) gebring word.

Die kern is dat in die Pastorale Briewe 'n baie innige verband gelê word tussen die optrede van die pastor in sy huis en in die gemeente. En ook hierin beklee die Heilige Gees 'n kardinale plek: 
In sy eie huis is die bedienaar se opdrag om ,goed te regeer" (prostènai - 1 Tim. 3:5).

In God se huis word vereis „ouderlinge wat goed regeer" (,proestotes presbuteroi" - 1 Tim. 5:17). Dieselfde begrip, „regering" - prohistamenos - word ook in Rom. 12:8 aangedui as 'n charisma van die Heilige Gees!

Die uiters belangrike konsekwensie is nou dat die pastor wat die charisma van ,,regering" deur sy optrede in sy eie huis verontagsaam, hom ook nie kan beroep op die leiding van die Heilige Gees vir sy optrede in die gemeente nie!

Aan die anderkant: As die pastor kragtens sy charisma van "regering" as Geesvervulde in sy eie huis optree, sal hy ook as Geesvervulde sorg kan dra vir die gemeente „die huis van God" (1 Tim. $3: 15$ ).

\section{Samevattende stellings}

1. Die Heilige Gees beklee die sentrale plek in die ampsgawe, die toebedeling van die ampsgawe en die aanwakker van die ampsgawe by die pastor.

2. Die Heilige Gees gee aan die pastor 'n charisma om deur die gemeente aangewys te word en aan die gemeente die charisma om die pastor aan te wys.

3. Die paraklese staan sentraal in die Pastorale Briewe. Parakleet en paraklese is onafskeidbaar verbonde.

4. Die vereistes van ingetoënheid en selfbeheersing wat aan die pastor gestel word, is by uitstek dié deugde van 'n lewe wat beheers word deur die Heilige Gees.

5. Die pastor wat sy eie huis nie goed regeer nie kan hom ook nie beroep op die leiding van die Heilige Gees vir sy optrede in die gemeente, „die huis van God" nie (1 Tim. 3:15).

Dr. C. J. H. Venter.

Meyerspark.

\section{LITERATUURVERWYSINGS}

1 Vgl. bv. wat Nederland betref Wurth, C. B.: Christelijke Zielszorg, p. 44-89; wat Amerika betref Hiltner, S.: Pastoral Counseling; wat SuidAfrika betref De Klerk, W. J.: Rousmart...; asook sy nuut verskene Pastorale Sensiwiteit. Wat Suid-Afrika betref het De Klerk baanbrekerswerk gedoen veral t.o.v. die plek van die Psigologie in die herderlike bediening.

2 Vgl. Venter, C. J. H.: By die sterfbed, p. 62-109.

3 De Klerk, W. J.: Rousmart... p. 97-155.

4 Vgl. bv. Gilhuis, C.: Pastorale zorg aan bejaarden, p. 26-95; Brouwer, H. J.: Pastorale begeleiding van bejaarden, p. $38-58$.

5 Vgl. ook in hierdie verband die werk van De Klerk, W. J.: Kerk en Pastoraat, asook sy: Die Pastorale gespreksontmoeting - 'n Prinsipiële studie.

6 Vgl. die aangehaalde werke van De Klerk en voetnote 1, 3, 5 van hierdie artikel. 
7 Vgl. Kotze, G. J.: Die Antropologiese onderbou van die Gereformeerde Pastoraat met besondere verwysing na die Amerikaanse Client-centered terapie.

8 De Klerk, J. J.: Die onderlinge vermaning in pastorale perspektief.

9 Conzelmann, charisma" - TWNT, 9, p. 394.

10 t.a.p.

11 t.a.p.

12 „kata” - Analytical Greek Lexicon, p. 213.

13 Rienecker, F.: Sprachlicher Schlüssel zum Griechischen Neuen Testament, p. 495.

14 Ridderbos, Herman: Pastorale Brieven, p. 125.

15 t.a.p.

16 Vgl. Firet, J.: Het Agogische Moment in het Pastoraal optreden, p. 54-109.

17 Schmitz, parakalein, TWNT, 5, p. 790.

18 a.w., p. 798.

19 t.a.p.

20 t.a.p. 